\title{
Die Ou-Testamentiese Wetenskap in die Fakulteit Teologie (Afd A), \\ Universiteit van Pretoria, 1917-1982
}

\author{
J P Oberholzer
}

Universiteit van Pretoria

\begin{abstract}
Old Testament Studies in the Faculty of Theology (Sec A), University of Pretoria, 1917-1982

Elsewhere in this volume short treatments of the theology and work of scholars in the Department of Old Testament Studies in the Faculty can be found. This article intends to give a brief survey of the University of Pretoria's earliest period of Hebrew and Old Testament Studies, as well as a general history of the Department during the 75 years of its existence.
\end{abstract}

Elders in hierdie uitgawe verskyn artikels oor bekleërs van die leerstoel Ou-Testamentiese Wetenskap en oor ' $n$ dosent in Argeologie. Daarmee is getrag om 'n oorsig te gee van hulle teologiese denke en arbeid. In hierdie artikel word kortliks aandag gegee aan die vroegste tydperk in die bestaan van die Fakulteit, naamlik van die stigting in 1917 tot en met Gemser se koms, toe Hebreeus en Ou-Testamentiese Eksegese telkens van dosente verwissel het en bowendien nie die aandag ontvang het wat dit toekom nie.

Hopelik sal by ' $n$ volgende geleentheid aandag gegee word aan die jonger kragte in die Departement, naamlik A P B Breytenbach, P M Venter en W C van Wyk, persone wat ten volle toegerus is om nie alleen predikante op te lei en te vorm nie, maar ook om die teologie te dien en te bevorder. 
Die studie van Hebreeus en die Ou Testament was van die begin af 'n vanselfsprekende onderdeel van die teologiese studie in hierdie Fakulteit. Nêrens in die beskikbare literatuur is daar sprake van 'n debat oor dié onderwerp nie. Dit blyk dat alle betrokkenes - universitêr en kerklik - die vanselfsprekende plek van die $\mathrm{Ou}$ Testament in die teologiese leerplan aanvaar het. In die vyfjarige BD-kursus wat tot 1924 gegeld het, is egter slegs vir 'n voorbereidende kursus in Hebreeus in die tweede studiejaar en 'n verdere eenjaarkursus in die derde studiejaar voorsiening gemaak, terwyl Grieks die eer van drie studiejare geniet het. Eksegese van die Ou en Nuwe Testament het in die vierde en vyfde studiejare aan die orde gekom (TUC Calendar 1919).

Vir Hebreeus was prof A C Paterson verantwoordelik. Hy was vanaf die stigting van die Transvaalse Universiteitskollege in 1908 tot met sy vertrek na Nieu Zeeland in 1924 professor in Klassieke Tale en Hebreeus en was daarnaas ook nog registrateur van die Universiteit van 1916 af en vanaf 1 Oktober 1918 af die eerste rektor. Alfred Croom Paterson is gebore op 12 Februarie 1875 in Dalry, Wes-Skotland en was afkomstig uit 'n predikantegesin. Nadat hy eers in Edinburgh 'n meestersgraad behaal het, gaan hy na Oxford waar hy 'n tweede MA in Moderne Tale en Lettere met lof ontvang. Hy kom in 1903 na Suid-Afrika as deel van die Milner-projek wat die verengelsing van die totale onderwysstelsel ten doel gehad het.

Vanaf 1905 is hy dosent in die Pretoriase Normaalkollege en in 1908 kry hy die professoraat aan die TUK. Hy is deur Greyvenstein beskryf as 'de knapste man voor Hebreeuwsch in geheel Zuid-Afrika' (Notule AKV 1919:28).

Tydens sy afwesigheid met verlof in 1918 is die lesings in Hebreeus waargeneem deur teologiese student P J J Venter. Dit het van die kant van die kuratorium bespreking en kritiek uitgelok en Greyvenstein moes 'n verduideliking oor die saak gee (Notule Kuratorium 29 Januarie 1918, 13 Maart 1918). In 1922-1923 was Paterson weer met verlof, en dié keer het ds E MacMillan die lesings waargeneem. Paterson het ná sy terugkeer van verlof nog net enkele maande sy pos beklee. Vroeg in 1924 vertrek hy na Nieu Zeeland waar hy 'n professoraat in Auckland aanvaar (Viljoen 1981:476). Ten spyte van verdeelde en onderbroke aandag aan die dosering van Hebreeus, kan aanvaar word dat Paterson goeie werk gedoen het. $\mathrm{Na}$ sy vertrek is die lesings in Hebreeus waargeneem deur prof S P Engelbrecht, die kerkhistorikus wat, naas sy eie vakgebied, ook nog Dogmatiek, Bybelse Teologie en die Geskiedenis en Filosofie van die Godsdiens moes behartig. Met die koms van Gemser in 1926 gaan die dosering van Hebreeus ' $n$ bestendige fase binne en word dit heg aan die Europese tradisie verbind.

Die Ieerplan vir Ou-Testamentiese Eksegese is in 1920 soos volg aangedui (TUC Calendar 1920:133 v): 
Fourth Year:

This course will include a detailed study of at least one narrative book and one or more prophetic or poetical books of the Old Testament, particular attention being paid to the composition and interpretation of the text. Opportunity will be taken to deal with any questions, doctrinal or ethical or historical which may naturally arise. General Introduction to Old Testament literature, including the questions of authorship, date etc.

Fifth Year: $\quad$ This course will include further study of the prophetical and poetical books of the Old Testament, with more detailed criticism of the text.

The Canon of the Old Testament, its formation and history.

Hierdie leerplan het in werking getree in 1920 toe die eerste studente wat die BDkursus gevolg het (H P Wolmarans en P S Grobler) in hulle vierde studiejaar gekom het. Voor dié tyd moes egter reeds leiding gegee word aan P J J Venter, wat nie vir $B D$ ingeskryf was nie, maar die kandidaatskursus gevolg het waarop die Kommissie van die Algemene Kerkvergadering van die Nederduitsch Hervormde Kerk en die Kuratorium op 12 Februarie 1914 besluit het, toe die voorneme bestaan het om 'n kerklike kweekskool te stig. Die kursus het 'n voorbereidende eksamen, 'n kandidaatseksamen in twee dele en 'n kerklike eksamen bevat en is verder gevolg deur 'n proponentseksamen (Notule Kommissie van die AKV 12 Februarie 1914). Venter se aantekeninge vir 1921 toon dat hy Psalm 49, Numeri 23 en Sagaria 5 gedoen het, vermoedelik met die oog op die proponentseksamen wat hy op 13 April 1921 moes aflê (Venter 1967:24). Die woordeboek wat hy gebruik het (tans in besit van die skrywer), was Gesenius-Buhl se elfde druk.

Die lesings in Ou-Testamentiese Eksegese is waargeneem deur ds Ebenezer MacMillan, predikant van die Presbiteriaanse Kerk in Pretoria. Hy was vanaf 1 April 1918 deeltydse dosent. Sy opleiding in Glasgow (MA, BD) het hom goed toegerus vir sy taak, maar sy teologie is deur sommige beskou as 'geheel modern' (Notule Kuratorium 22 Julie 1919). Hy het nogtans sy werk voortgesit en is op 27 Oktober 1924 tot deeltydse professor bevorder. In dieselfde jaar is hy verkies as moderator van die Algemene Vergadering van die Presbiteriaanse Kerk in Suid-Afrika. Sy aansluiting by die Oxfordgroep in 1929 het egter steeds meer van sy tyd in beslag geneem. In 1930 gaan hy na Skotland en Engeland as verteenwoordiger van die Oxfordgroep van Suid-Afrika. In dieselfde tyd ontvang hy 'n eredoktoraat van Glasgow (Notule van die Fakulteit Teologie 29 Augustus 1930). Teen dié tyd was die lesings in die Ou-Testamentiese vakke egter reeds in die bekwame hande van Gemser.

Tydens ds MacMillan se afwesigheid met verlof in 1920 is die lesings in die Eksegese van die Ou Testament waargeneem deur prof Paterson en ds S Menzies 
(Notule Kuratorium 4 Junie 1920). Navraag by die Presbiteriaanse Kerk het laat blyk dat William Menzies, 'n besondere taalkenner en alumnus van Glasgow Universiteit, oor die jare 1918 tot 1925 predikant te Premiermyn was. Vermoedelik is hy die persoon na wie verwys word.

Die leerstoel waarin Gemser deur die TUK benoem is, is dié in 'Semitics', wat tot stand gekom het as 'n departement in die Fakulteit Lettere en Wysbegeerte met behulp van skenkings van Joodse firmas. Hierdie skenkings is aanvanklik vir 'n tydperk van vyf jaar onderneem en het 'n totale bedrag van 75 pond per jaar bedra. Enkele firmas het hulle donasies tot diep in die dertigerjare voortgesit, onder andere die Transvaal Trading Company en die Pretoria West Milling Company. Rabbi Hirsch van die Pretoria Hebrew Congregation was die tussenganger en het in sy aanbiedingsbrief van 25 September 1925 onder andere geskryf: 'I hope that in appointing a Professor for Hebrew the requirements of the Jewish students who may form a fair percentage of those who will persue this subject at the TUC will be taken into consideration.'

In werklikheid het die leerstoel inderdaad groot waarde gehad veral vir nagraadse studie van Joodse studente. Verskillende rabbyne het onder Gemser en Van Selms gestudeer, gewoonlik met Nieu-Hebreeus as hoofvak. Minstens een het ook in Hetities gespesialiseer.

Met Gemser se koms kry Hebreeus ook volwaardige status wat as driejarige hoofvak vir BA geneem kon word. Gemser is tegelykertyd deur die kerk as hoogleraar in die Ou-Testamentiese vakke benoem (Notule Kuratorium 12 November 1925). Hy het dus van die staanspoor af twee leerstoele gevul, en het bowendien ook nog verantwoordelikheid aanvaar vir Antieke Kultuurgeskiedenis. Met sy toetrede tot die dosentekorps begin in 1926 'n bloeityd in die beoefening van die Semitiese taalwetenskap en die Ou-Testamentiese Wetenskap. Nadat hy eers tydelikdeeltydse hulp in Semitiese Tale gekry het in die persoon van P F D Weiss, 'n leerling van Gemser en later hoogleraar in Semitiese Tale in Stellenbosch, kom in 1938 behoorlike hulp in die persoon van Van Selms as senior lektor. Van Selms neem vanaf 1948 die Departement Semitiese tale volledig oor en Gemser kan hom dus tot met sy emeritaat in Junie 1955 volledig aan die Ou-Testamentiese Wetenskap wy (Ad Destinatum 1960:168-169).

Bybelse Argeologie het al vroeg 'n beskeie plek gehad in die leerplan van die Fakulteit. Reeds in die konsep-leerplan vir BD wat op 5 Maart 1919 deur die Kuratorium goedgekeur is, word 'n 'argeologiese onderwerp' in die vierde of vyfde jaar genoem. In die rapport van die Kuratorium aan die Algemene Kerkvergadering van 1919 verskyn dit as 'n 'sociologisch onderwerp'. In die verslag van prof Greyvenstein aan die Kuratorium word vermeld dat twee studente naas die vakke wat vir BD 1 
vereis word, ook lesse geneem het in Ensiklopedie en Hebreeuse Argeologie (Notule AKV 1919:137, 139). In die leerplan wat in die TUC Calendar opgeneem is, word vir 1920 in die tweede jaar "n voorlopige nie-kwalifiserende kursus in Hebreeus en Hebreeuse Oudheidkunde' genoem. Dit kom voor of die Argeologie/ Oudheidkunde dan vir 'n tyd nie aan die orde gekom het nie en eers weer met Gemser se koms hervat is. In die jaarboek van 1932 word vir die eerste keer'n omskrywing van Oudheidkunde gegee, naamlik die geskiedenis en resultate van die opgrawings en die huislike, maatskaplike en staatkundige verhoudinge in Oud-Israel. Die voorgeskrewe boeke vir dié doel was Paul Volz se Bihlische Altertümer en F M Th Böhl se Palestina. Sindsdiens het Argeologie/Oudheidkunde sy vaste plek in die leerplan behou. Vanaf 1938 is hierdie vak in die Fakulteit behartig deur Van Selms en vanaf 1963 tot 1970 deur E S Mulder. J P Oberholzer het na sy toetrede tot die Fakulteit die werk voortgesit, maar dit spoedig oorhandig aan W C van Wyk, die begaafde opvolger van Van Selms in die leerstoel Semitiese Tale. (Die Bybelse Argeologie word steeds ' $n$ belangrike hulpwetenskap vir die studie van die Ou Testament geag en is steeds in die hande van Van Wyk, tans dekaan van die Fakulteit Lettere en Wysbegeerte.)

Gemser is ná sy emeritaat opgevolg deur E S Mulder, alumnus van die Fakulteit en doktorale leerling van de Groot en Vriezen. Mulder (Ad Destinatum 2:115, 116) het die histories-kritiese benadering van sy voorganger voortgesit en dit verbind met 'n besondere teologiese diepgang. Sy vyftienjarige professoraat (1956-1970) val egter saam met besondere woelinge op kerklike en politieke gebied waarin hy self ' $n$ aktiewe rol speel en waarin die Fakulteit gaandeweg in 'n mate van isolasie te staan kom, veral ten opsigte van die Nederlandse akademiese wêreld. Hierdie isolasie, wat hoofsaaklik van Nederlandse kant bewerk is, het egter slegs ten gevolg gehad dat meer aandag aan Duitse en Engelse werke gegee is. Daarby het die Engelssprekende wêreld sterk op die voorgrond begin tree op die gebied van die Bybelwetenskappe, sodat dit moontlik geword het om meer voorgeskrewe werke uit Brittanje en Amerika in die leerplan in te sluit. Die klein Afrikaanse taalwêreld maak dit steeds moeilik om handboeke in Afrikaans tot beskikking te hê, veral ook nog as in aanmerking geneem word die klein getal potensiële gebruikers in die Nederduitsch Hervormde Kerk.

Die grondslae wat Gemser en Van Selms gelê het, het ten spyte van beperkende faktore, onveranderd gebly. Miskien het daar deur die jare 'n groter klem gekom op die predikgerigtheid van die eksegese en die eise wat die ampspraktyk aan die teoloog stel. Dit is in die hand gewerk deur die besondere betrokkenheid van dosente in die Teologie by die kerklike werk, veral ook by sinodale vergaderinge. 
Lede van die Fakulteit en spesifiek Bybelwetenskaplikes, het 'n besondere rol gespeel in die prosesse van Afrikaanse Bybelvertaling. Wat die Ou Testament betref, het Van Selms en Mulder, later Mulder en Oberholzer, reeds deel gehad aan die stadium toe ' $n$ hersiening van die 1933-1953-Bybel aan die orde was, terwyl Mulder, Oberholzer en Breytenbach kon deel in die totstandkoming van die Nuwe Afrikaanse Vertaling wat in 1983 verskyn het, met, naas hulle, nog 'n wyer kring uit die alumni van die Fakulteit wat as adviseurs opgetree het.

Die toetrede van A P B Breytenbach tot die voltydse personeel van die Departement Ou-Testamentiese Wetenskap het geskied om dit vir Oberholzer moontlik te maak om met die Bybelvertalingsprojek voort te gaan, iets wat altesaam dertien jaar geduur en in sommige jare soveel as twintig en meer sittingsweke in beslag geneem het. Vanaf 1980 kon die Departement hom dus verheug in twee voltydse personeellede, naas ook nog die dosent in Bybelkunde, P M Venter. Die drie Ou-Testamentici in die Fakulteit is almal alumni van die Fakulteit.

Die instelling van die vak Bybelkunde in die Fakulteit Lettere en Wysbegeerte het geskied op versoek van die twee kerke wat by die Fakulteit Teologie se twee afdelings betrokke is. Die aanbieding het aanvanklik ook op koste van die kerke geskied. Dit het die voordeel gebring van 'n addisionele leerkrag vir elk van die twee Bybelwetenskappe.

Die ingrypende veranderinge wat op die gebied van die tersiêre onderwys-metodiek ingetree het, is in die Ou-Testamentiese Wetenskap ten volle verdiskonteer. Groter klem op selfwerksaamheid aan die hand van studiehandleidings, gekonsentreerde aanbieding en afhandeling van een vak op 'n keer en intensiewe gebruik van beskikbare tyd, laat die akademiese toneel heel anders uitsien as in vroeër dae. Daarby kom groter klem op die teologiese inhoude van die Bybelboeke, met die uitgangspunt dat ons in hierdie boeke voluit te doen het met God se Woord wat terselfdertyd voluit mensewoord is.

\section{Literatuurverwysings}

Ad Destinatum 1960. Gedenkboek van die Universiteit van Pretoria. Johannesburg: Voortrekkerpers.

Ad Destinatum 2 1970. 'n Geskiedenis van die Universiteit van Pretoria in opdrag van die Universiteitsraad saamgestel deur $\mathbf{F} \mathbf{J}$ du Toit Spies en D H Heydenrych. Pretoria: Universiteit van Pretoria.

Nederduitsch Hervormde Kerk van Afrika 1914, 1919. Notules van die Kommissie van die Algemene Kerkvergadering van die Nederduitsch Hervormde Kerk. Pretoria: NHKA. 
Nederduitsch Hervormde Kerk van Afrika 1918, 1920, 1925. Notules van die Kuratorium vir die Teologiese Opleiding van die Nederduitsch Hervormde Kerk. Pretoria: NHKA.

Nederduitsch Hervormde Kerk van Afrika 1919. Notule der Algemene Kerkvergaderingen der Nederduitsch Hervormde Kerk van Zuid-Afrika gehouden te Pretoria op de 20ste November 1917 en op de 12de Juni 1919 en volgende dagen. Pretoria: NHKA.

Universiteit van Pretoria 1919, 1920. Transvaal University College Calendar. Pretoria: UP.

Venter, P J J 1967. Erns en pret in die kerklike lewe. Die Hervormer Maart 1967, bl 24.

Viljoen, G van N 1981. Paterson, Alfred Croom. SABW 5, 476. 